\title{
KEPEMIMPINAN MODEL GEMBALA
}

Oleh Pdt. Dr. Daniel Ronda, Th.M.

\section{TEKS ALKITAB PENUNTUN}

Yohanes 10:11: "Akulah gembala yang baik. Gembala yang baik memberikan nyawanya bagi domba dombanya."

I Petrus 5:4: "Maka kamu, apabila Gembala Agung datang, kamu akan menerima mahkota kemuliaan yang tidak dapat layu."

Mazmur 78:72: "Ia menggembalakan mereka dengan ketulusan hatinya, dan menuntun mereka dengan kecakapan tangannya."

Yesaya 11:5: "Ia tidak akan menyimpang dari kebenaran dan kesetiaan, seperti ikat pinggang tetap terikat pada pinggang."

\section{PENDAHULUAN}

Mengawali tulisan ini, saya ingin memulai dengan perenungan: Apakah menurut pengamatan sebagai pemimpin, para pemimpin gereja saat ini di sekitar kita saat ini sedang memimpin dengan hati gembala (herding leadership) atau gaya "herder" (analogi anjing jenis herder)? Pertanyaan ini saya ajukan karena memimpin bukan hal mudah, tetapi membutuhkan sesuatu kemampuan khusus dari Tuhan, sementara banyak pemimpin yang putus asa terhadap pengaplikasian prinsip kepemimpinan dan memilih jalan pintas yaitu dengan cara "herder" yaitu gaya otokratik dan bahkan kekerasan. Sonny Eli Zaluchu dalam tulisannya tentang Intrik di Dalam Gereja mengatakan bahwa "Kelemahan kepemimpinan gembala biasanya ditandai dengan sejumlah aktifitas yang cenderung memaksakan kehendak, gaya penggembalaan yang tidak berkenan, mulut yang tidak terkontrol, menguatnya pengaruh dan intervensi orang-orang tertentu di dalam keputusan gembala (orang kuat, anak, menantu), visi yang lemah, doa yang kurang dan sikap yang mencerminkan kekunoan (seperti plin-plan, tidak mau mengakui kesalahan dan sikap tidak mau tahu). Hal yang paling utama adalah gembala yang tidak mau berubah dan selalu tertutup menerima masukan karena menganggap diri benar. " Jalan ini seringkali diambil karena paling "aman" yaitu adanya anggapan bahwa mereka (baca: pengikut atau jemaat) tidak perlu tahu. Namun seperti yang kita sudah ketahui bersama, model dari kepemimpinan "herder" ini menghasilkan kehancuran baik diri sendiri maupun organisasi yang dipimpinnya.

Seharusnya menurut pendapat saya, memimpin dengan hati gembala adalah berbicara tentang melayani, menuntun, mengarahkan, menantang, dan 
membantu orang lain dan organisasi untuk bertumbuh. Kepemimpinan gembala tidak berbicara soal aktivitas manajemen belaka, namun menumbuhkan orang yang kita pimpin. Itu sebabnya mengawasi dan menuntun yang dipimpin akan lebih mudah dan akan menunjukkan hasil yang berbeda. Sudah dibuktikan bahwa orang yang dipimpin tidak dapat digerakkan dimotivasi oleh sebuah birokrasi atau prosedur sebagaimana teori manajemen. Orang hanya digerakkan oleh visi, nilai-nilai, prinsip-prinsip dan keyakinan tentang diri (Robert J. Stevens).

Hal ini diperkuat juga oleh seorang tokoh kepemimpinan dari India Anthony D'Souza, yang mengatakan tentang kepemimpinan gembala sebagai berikut:

Bagi pemipin-gembala, produknya adalah para pengikut. Bukan keuntungan, bukan pangsa pasar. Para pengikut itu sendiri yang menjadi tujuan dan produk dari upaya pemimpin-gembala. Dan, karena itu, ketika dombanya tetap hidup menghadapi berbagai bahaya dalam perjalanan, ketika mereka bertambah kuat, gembala dengan setia menunaikan tugasnya. Domba memang harus dibimbing, didorong, dan dimotivasi untuk mencapai kinerja terbaik. Namun, domba-domba inilah yang memenuhi [hati]pemimpin-gembala ketika tidur di malam hari dan yang pertama dicari ketika sinar mentari pagi menandai setiap hari baru. Gembala benar-benar merupakan pelayan domba-dombanya. Pertumbuhan dan pemeliharaan terhadap mereka menjadi tugas dan agendanya dalam mencapai sukses (28-9).

Tetapi dalam pengamatan saya, masalah yang terbesar dihadapi beberapa pemimpin Kristen adalah memiliki minat yang rendah dengan orang-orang serta tidak memiliki kemampuan menjalin hubungan dengan rekan-rekan (interpersonal relationship) dan tidak peduli kepada masalah-masalah emosional orang yang dipimpinnya. Hal lain adalah adanya sikap pesimis terhadap kehidupan di depan sehingga menurunkan semangat organisasi yang dipimpinnya. Ciri lainnya yang paling banyak muncul dalam kepemimpinan adalah bersikap antisosial, skeptis, kurang senyum, suka mendominasi dan agresif. Padahal ini berlawanan dengan kepemimpinan dengan hati gembala.

Fakta lain adalah pemimpin apapun jenisnya senang pendidikan formal, training, menghargai prinsip-prinsip kepemimpinan, dan juga kemampuan manajemen. Tetapi ada kelemahan mendasar kalau tidak memiliki kepemimpinan gembala yaitu hubungan (relationship). Padahal kepemimpinan yang efektif sebagaimana yang ditemukan dalam riset pakar kepemimpinan Kouzes dan Posner bahwa "kepemimpinan adalah 
hubungan (leadership is a relationship)". Mereka berdua berkata, "Kepemimpinan adalah sebuah hubungan. Kepemimpinan merupakan hubungan antara mereka yang terpanggil untuk memimpin dan mereka yang memilih untuk mengikuti. (Versi Inggrisnya: Leadership is a relationship between those who aspire to lead and those who chose to follow. Sometimes the relationship is one-to-many. Sometimes it's oneto-one. But regardless of whether the number is one or one thousand, leadership is a relationship). (21)"

Satu hal lagi yang diingatkan oleh Dr Stacy Rinehart dalam bukunya Upside Down yang berkata: "Banyak orang sudah tahu resep Yesus untuk sukses kepemimpinan yaitu 'Tidaklah demikian di antara kamu. Barangsiapa ingin menjadi besar di antara kamu, hendaklah ia menjadi pelayanmu, dan barangsiapa ingin menjadi yang terkemuka di antara kamu, hendaklah ia menjadi hamba untuk semuanya (Markus 10:43-44)', tetapi ketika hal ini hendak diterapkan dalam hal praktis, banyak pemimpin tidak mau memakai nasehat Yesus ini dan malahan menerapkan tren kepemimpinan duniawi". ["Most believers are familiar with Jesus' recipe for leadership success ("Whoever wants to become great among you must be your servant, and whoever wants to be first must be slave of all" [Mark 10:43-44 NIV]), but when it comes to putting that into practice, many leaders are content to leave Jesus' advice on a dusty road in Galilee and follow society's leadership trends."] Banyak pemimpin mencoba mengikuti tren kepemimpinan dan melupakan prinsip Yesus tentang kepemimpinan gembala.

\section{PRINSIP-PRINSIP KEPEMIMPINAN GEMBALA (HERDING LEADERSHIP)}

Untuk itu pada orasi pagi ini, saya ingin menguraikan secara sederhana beberapa prinsip kepemimpinan gembala yang biblika yang sudah banyak juga diadopsi oleh tren teori kepemimpinan secara umum.

\section{KEBAIKAN}

Memimpin dengan kebaikan harus berpola kepada kebaikan hati Allah. Dalam teologi kata kebaikan (goodness atau chrestotes dalam bahasa Yunani) diidentikkan dengan kemurahan Allah (di bawah pembahasan Allah Mahakasih). Albert Barnes (teolog) memberikan arti kata ini sebagai kindness yaitu kebaikan hati, keramahan, perbuatan baik, kasih sayang. Allah baik di mana Ia penuh dengan belas kasih, baik hati, anugerah, mementingkan kepentingan orang lain (altruisme). Sehingga Allah yang penuh dengan kebaikan berarti Allah yang mengasihi umatNya, Allah yang lemah lembut, baik hati dan selalu memberikan anugerah baik dalam Perjanjian Lama sampai dengan Perjanjian Baru. Kasih setia 
Allah dicurahkan kepada umat-Nya, Israel, meskipun mereka terus berdosa. Ketika Allah harus menghukum Israel karena kebebalan hati mereka yang terus menyembah berhala, Ia tetap mengasihi mereka, sehingga setelah mereka bertobat Allah tetap mengasihi dan memulihkan keadaan mereka, yang walaupun kebaikan Allah tidak pernah boleh dipisahkan dengan keadilan Allah (lihat Denny Teguh Sutandio).

Pemahaman teologi ini akan menolong kita dalam mengaplikasikan kebaikan dalam kepemimpinan kita. Sifat moral Allah yang mahabaik menantang pemimpin Kristen untuk memiliki kebaikan moral dan semangat alturisme dalam karakternya.

\section{KETULUSAN HATI}

Ketulusan hati berbicara tentang integritas seorang pemimpin. Raja Daud dikatakan bahwa "Ia menggembalakan umat Israel dengan ketulusan hatinya, dan menuntun (memimpin-led) mereka dengan kecakapan tangannya" (Mazmur 78:72). Itu sebabnya memiliki kompetensi dalam kepemimpinan saja tidak cukup, dibutuhkan juga ketulusan hati.

Ketulusan hati tercermin dalam integritas kehidupan seorang pemimpin. Rendahnya integritas telah menjadi masalah kepemimpinan Kristen. John Maxwell mengatakan bahwa di dalam sebuah survei di Amerika yang ditujukan kepada kurang lebih 1300 para pimpinan perusahaan dan pejabat di pemerintahan, mereka ditanya kualitas apakah yang paling penting dimiliki untuk dapat sukses menjadi pemimpin. Jawabannya menarik karena secara mayoritas (71\%) mereka memilih jawaban sebagai yang terpenting: integritas (173).

Arti kata integritas adalah keadaan yang sempurna, di mana perkataan dan perbuatan menyatu dalam diri seseorang. Seseorang yang memiliki integritas tidak meniru orang lain, tidak berpura-pura, tidak ada yang disembunyikan, dan tidak ada yang perlu ditakuti. Kehidupan seorang pemimpin adalah seperti surat Kristus yang terbuka (Il Kor 3:2).

Integritas sebagai karakter bukan dilahirkan, tetapi dikembangkan secara satu lepas satu di dalam kehidupan kita melalui kehidupan yang mau belajar, keberanian untuk dibentuk Roh Kudus. Itu sebabnya seorang pemimpin terkenal berani berkesimpulan, bahwa karakter yang baik akan jauh lebih berharga dan dipuji manusia dibandingkan dengan bakat atau karunia yang terhebat sekalipun. Kegagalan sebagai pemimpin bukan terletak kepada strategi dan kemampuannya dalam memimpin, tetapi kepada tidak adanya integritas pada diri pemimpin (Lihat Maxwell, 178).

Itu sebabnya memimpin tidaklah mudah. Ada ungkapann yang berkata bahwa , "Pemimpin laksana ikan dalam akuarium (fishbawl) di mana semua 
segi kehidupannya diamati dan diawasi orang lain. Menariknya, orang lebih mengingat kejelekan kita daripada kebaikannya." Memang kepemimpinan selalu menjadi sorotan dan ketika seseorang menjadi pemimpin, orang mulai menyoroti kelemahannya, tetapi dengan mengembangkan integritas akan menolong kita menghadapi hal ini.

\section{KECAKAPAN}

Memimpin dengan kecakapan berarti memiliki kompetensi, kemampuan serta keahlian. Menurut Dr. Yakob Tomatala, kompetensi meliputi banyak hal yaitu meliputi kompetensi karakter, pengetahuan, dan keahlian (Lihat Kepemimpinan yang Dinamis: 235-34l). Dalam orasi ini saya khusus mengambil dua hal dari kompetensi keahlian yang menolong menguatkan kepemimpinan gembala kita yaitu kecakapan hubungan antar manusia (relationship) dan kecakapan keahlian teknis. Sebagaimana diringkas oleh Dian Pradana, maka kompetensi yang dimaksud oleh Dr. Tomatala itu meliputi dua hal.

Pertama, kecakapan yang berkenaan dengan "hubungan antar manusia" atau disebut juga "keterampilan atau kecakapan sosial". Seorang pemimpin yang baik tidak hanya menyadari bahwa ia membutuhkan orang lain, tetapi ia juga dengan penuh tanggung jawab dapat membina hubungan baik dengan orang lain yang menjamin kerja sama yang baik dan keberhasilan kerja. Hubungan baik dengan orang lain harus dimulai oleh pemimpin. Ia harus memiliki tekad untuk menyukainya, menghidupinya dengan melaksanakannya dengan penuh tanggung jawab. Prinsip kepemimpinan Tuhan Yesus tetap berlaku di sini, yaitu: "Segala sesuatu yang kamu kehendaki supaya orang perbuat kepadamu, perbuatlah demikian juga kepada mereka" (Matius 7:12). Tekanan utama yang diberikan di sini adalah bahwa apa saja yang dilakukan oleh seorang pemimpin, mencerminkan apa saja yang akan/nanti/ telah diperbuat orang kepadanya. Apabila pemimpin menghendaki dan melaksanakan/membina hubungan baik dengan siapa saja, ia pun akan menerima kebaikan dari tindakannya.

Kedua, kecakapan yang berkaitan dengan "hubungan pelaksanaan tugas" di mana seseorang yang disebut ahli itu tahu dan dapat melakukan tugasnya dengan baik dan benar. Keterampilan atau keahlian atau kecakapan tugas berkaitan erat dengan hal-hal praktis yang bersifat teknis, sehingga dapat juga disebut keahlian teknis/praktis. Keahlian ini berkaitan erat dengan "bagaimana melaksanakan tugas", yang harus dilaksanakan dengan baik dan . pemimpin harus memiliki keahlian khas, khususnya yang berkenaan dengan kecakapan memimpin. 
Itu sebabnya dalam memimpin, seseorang tidak boleh pernah berhenti belajar baik dalam bentuk formal ataupun informal. Pembelajaran yang terus menerus akan menghasilkan kecakapan yang lebih banyak lagi. Pembelajaran tidak berfokus kepada gelar, namun kepada pemenuhan salah satu kunci sukses pemimpin-gembala yaitu cakap, yang meliputi cakap mengajar, cakap berelasi, dan cakap memimpin.

\section{KESETIAAN DALAM KEBENARAN}

Kata kesetiaan adalah penting dalam kosakata teologi Kristen dan juga pemimpin-gembala. Setidaknya dalam Perjajian Lama maupun Perjanjian Baru pemimpin dituntut Tuhan untuk mencintai kesetiaan (love mercy) disamping adil dan hidup dengan rendah hati di hadapan Allah (Mikha 6: 8). Kesetiaan harus ditunjukkan disamping kasih sayang kepada masing-masing sebab Tuhan akan menjadi Allah mereka dalam kesetiaan dan kebenaran (Zakaria 7:9 dan 8:8). Setidaknya ada tiga sebab mengapa kesetiaan itu penting. Pertama, kesetiaan adalah yang terpenting dalam hukum Taurat (Matius 23:23); kedua, kesetiaan salah satu buah Roh Kudus yang harus ada dalam kehidupan kita (Galatia 5:22); ketiga, kesetiaan merupakan salah satu yang harus dikejar disamping keadilan, kasih dan damai (II Timotius 2:22).

Dalam pengamatan saya, banyak ahli kepemimpinan tidak suka kata kesetiaan, karena beranggapan bahwa kata ini sering kali disalahgunakan sebagai tameng untuk berlindung dari kegagalan memimpin. Walaupun demikian, kesetiaan tidak boleh dihilangkan dalam kamus pemimpin-gembala, karena tanpa kesetiaan, maka kita tidak berhak menuntut loyalitas yang sama kepada pengikut kita. Justru ini yang menjadi kunci keberhasilan pemimpingembala.

\section{KESIMPULAN}

Tren kepemimpinan telah berkembang sangat pesat dan dapat dengan mudah dipelajari secara mandiri. Bahkan nilai dan prinsip biblika telah mewarnai semua lini prinsip ilmu kepemimpinan. Namun dalam lini praktika, kita diperhadapkan dengan kompleksitas kultural, masalah sosial, dan konteks yang sangat beragam. Saat ini kita tidak boleh berhenti dengan penerapan kepemimpinan dalam kehidupan kita. Ada banyak keunikan yang akan kita temukan di lapangan. Seperti kata Robert Clinton, kita sedang memasuki "universitas kehidupan" ("university of life"), di mana penerapan nilai kepemimpinan tidak pernah berhenti. Nilai-nilai itu harus terus digali dan diaplikasikan.

Salah satu hal yang menjadi solusi dalam kepemimpinan sat ini adalah perlunya pengembangan kepemimpinan yang berhati gembala. Nilai ini bersumber dari Yesus sendiri.lewat hidup dan pengajaranNya. Prinsip itu 
didasarkan kepada kebaikan, ketulusan hati, kecakapan, dan kesetiaan dalam kebenaran. Prinsip ini kekal, namun penerapannya membutuhkan waktu dan kerja keras di dalam konteks masyarakat pascamodernitas ini.

Mengakhiri tulisan ini saya mengajak kita merenungkan kembali pernyataan Anthony D'Souza tentang hasil dalam menerapkan pemimpingembala:

Oleh karena itu, gembala adalah model bagi para pemimpin dari segala organisasi, termasuk perusahaan industri dan komersial. Pemimpin dituntut untuk bertindak sebagai gembala sejati atas organisasinya, yang pertama-tama dan terutama dilihat sebagai komunitas manusia. Dengan demikian, pemimpin semacam ini akan memperoleh loyalitas dan komitmen dari para pegawai dan pelanggan, dan pada gilirannya akan meraih apa yang tidak pernah dapat diperintahkan oleh pemimpin lain (29).

Sekali lagi berkat dan sukses kepemimpinan adalah bila dikembangkan model kepemimpinan gembala. Loyalitas pengikut dan pengembangan organisasi adalah suatu pencapaian yang terjadi sebagai akibat dari pengembangan kepemimpinan gembala secara konsisten.

\section{Works Cited}

D'Souza, Anthony. Proactive Visionary Leadership. Jakarta: Trisewu, 2007.

Kouzes, James M. \& Barry Z. Posner. The Leadership Challenge (Tantangan Kepemimpinan). Edisi Ketiga. Terj. Revyani Sjahrial. Jakarta: Erlangga, 2004.

Maxwell. John C. Developing the Leaders Within You. Nasville: Thomas Nelson, 1993.

Rinehart, Stacy. Upside Down. USA: NavPress, 1998. Tersedia di http:// www.navpress.com/Store/Product/9781576830796.html. Diakses 1 Juni 2008.

Stevens, Robert J. Management Versus Leadership. 28 Februari 2006. Diakses 14 Mei 2008. Tersedia di http://herdingcats.typepad.com/ my_weblog/2006/02/management_vers.html.

Sutandio, Denny Teguh. Murka Allah Terhadap Kebebalan Manusia dan Pentingnya Pertobatan. Tersedia di http://dennytan.blogspot.com/2007/ 06/roma-23-4-murka-allah-terhadap.html. Diakses 1 Juni 2008. 
Tomatala, Yakob. Kepemimpinan yang Dinamis. Malang: Gandum Mas, 1997 (diringkas oleh Dian Pradana, tersedia di http://www.sabda.org/lead/ htm/menemukan_pemimpin_kompeten.htm, diakses 1 Mei 2008)

Zaluchu, Sonny Eli. Intrik dalam Gereja. http://www.glorianet.org/kolom/ kolointr.html; Gloria Cyber Ministries, Diakses 14 Mei 2008. 